\title{
Liquidity, Profitability And Operational Costs On Corporate Income Tax
}

\author{
Bertilia Lina Kusrina ${ }^{1}$, Putri Desti Fatwah Fatimah ${ }^{2}$ \\ ${ }^{12}$ Faculty of Economic, Gunadarma University, Jakarta, Indonesia \\ ${ }^{1}$ Correspondent: 1kusrina@staff.gunadarma.ac.id ${ }^{1}$
}

$\begin{array}{ll}\text { Received } & \text { : August 08, } 2021 \\ \text { Accepted } & \text { : August 25, } 2021 \\ \text { Published } & \text { : October 31, } 2021\end{array}$

Citation: Kusrina, B.L., Fatimah, P.F. (2021) Liquidity, Profitability And Operational Costs On Corporate Income Tax. Ilomata International Journal of Tax \& Accounting 2(4),236-245.

https://doi.org/10.52728/ijtc.v2i4.335

\begin{abstract}
Tax revenue is the largest source of income for the Indonesian state. One of the contributors to state revenue from the tax sector is corporate income tax. Financial performance is one measure of the success of a business entity which is expected to increase revenue from corporate income tax.

This study aims to determine the effect of financial performance using variable liquidity ratios, profitability ratios, and operating costs on corporate income tax. The data used is secondary data, namely annual financial report data from large trading sub-sector companies (wholesale) listed on the Indonesia Stock Exchange (IDX) for the 2014-2018 period. The analytical method used is multiple regression analysis. The results showed that partially profitability and operating costs have an effect on corporate income tax, while liquidity has no effect on corporate income tax. Simultaneously, liquidity, profitability and operating costs affect corporate income tax. Based on the results obtained that the ratio that affects corporate income tax is profitability and operating costs, so as an implication the internal party/management must be careful with the information presented in the financial statements which will have a negative impact on the users of financial statements, especially on operating costs.
\end{abstract}

Keywords: Liquidity, Profitability, Operational costs, Corporate Income Tax

(c) This is an open access article under the
CC-BY 4.0 license.

\section{INTRODUCTION}

Company taxes, also called corporate taxes, are direct taxes levied by the government or tax authorities on corporate income. Corporate taxes are imposed nationally, but corporate taxes can also be levied at the regional level. In general, taxes are imposed on the company's income or capital. Corporate tax usually applies to local companies incorporated in a country, foreign companies that do business in a country and earn income from their business, a foreign company that has a business license in a country, and the company is owned by a resident of a country. (Ježek, 2014)

Taxable corporate income is often determined based on the taxable income of individual taxpayers. The tax imposed is based on the company's net profit. In some jurisdictions, the rules for tax companies may differ significantly from the rules for individual taxes. Certain corporate actions, 
such as reorganization, may not be taxed. Certain types of entities may be exempt from taxes. (Farah et al., 2021)

The state can tax the company on its net income and can also tax the shareholders when the company pays dividends. Where dividends are taxed, companies may be required to withhold taxes before the dividends are distributed. (Zhang \& Huang, 2014)

Companies in Indonesia must pay corporate income tax no later than the end of the fourth month of each year by submitting a corporate income tax return. Tax payments are made through the nearest bank or tax service office. A copy of the proof of tax payment is attached to the Annual SPT. The extension can be valid for a maximum of two months if you submit written notification to the Directorate General of Taxes before the SPT deadline. (Direktorat Jenderal Pajak, 2013)

Up to date, taxes are the biggest source of income in Indonesia. From the data on the state budget of revenues and expenditures in 2018, of the state revenue at Rp 1.894 .73 trillion rupiah, the 1.618,1 trillion came from taxation or it is 85 percent of the state revenue. Likewise, in 2019, 1.786,4 trillion rupiah came from taxes, which was 82.5 percent of the total state revenue which amounted to $2.165,1$ trillion rupiah. Although the percentage of the proportion of tax revenue from the total receipts in the state budget decreased from 2018 to 2019 but the acceptance of taxation from 2018 to 2019 increased at 168.3 trillion. From this proportion, it can be seen that tax revenues are still expected to be the backbone of national income.

Tax revenue cannot be separated from taxpayer compliance in fulfilling their tax obligations. Taxpayers are individuals or entities, including taxpayers, tax withholder, and tax collectors, who have taxation rights and obligations in accordance with the provisions of the legislation of taxation. This means that tax revenues depend on the compliance of individuals or entities that fulfill their obligations in paying taxes. The more people or corporations that pay taxes, the more income from the tax sector. (Direktorat Jenderal Pajak, 2013)

Table 1.

State Revenues in 2018 and 2019 (In Trillion Rupiah)

\begin{tabular}{crr}
\hline \multicolumn{1}{c}{ DESCRIPTION } & \multicolumn{1}{c}{2018} & \multicolumn{1}{c}{2019} \\
\hline STATE INCOME & $1.894,73$ & $2.165,10$ \\
\hline Domestic Income & $1.893,53$ & $2.164,70$ \\
\hline 1. $\quad$ Taxation Receipt & $1.618,1$ & $1.786,40$ \\
\hline 2. Non-Tax Revenue & 275,43 & 378,30 \\
\hline Grant Receipt & 1,2 & 0,40 \\
\hline
\end{tabular}

Source: Ministry of Finance (Kemenkeu)

Seen from the APBN realization report (table 2.), income tax is the highest contributor to tax revenue compared to value added tax revenue and others. Of the total tax revenue, each accounted for 60 percent and 57 percent in 2018 and 2019 of the total tax revenue. This proves that income tax must be considered in its receipt.

Table 2 .

Realization of tax revenue for 2018-2019 
Liquidity, Profitability And Operational Costs On Corporate Income Tax Kusrina \& Fatimah

\begin{tabular}{ccc}
\hline \multicolumn{3}{c}{ (In trillion rupiah) } \\
\hline & 2018 & 2019 \\
\hline Income tax & 855,13 & 894,44 \\
\hline non-oil & 817,00 & 828,29 \\
\hline oil and gas & 38,13 & 66,15 \\
\hline VAT \& Luxury Goods Tax & 541,80 & 655,39 \\
\hline Tand and Building Taxes \& other taxes & 27,06 & 27,71 \\
\hline Tax revenue & $1.423,99$ & $1.577,54$ \\
\hline
\end{tabular}

Source: Ministry of Finance (Kemenkeu)

According to the tax law No. 36 of 2008 concerning income tax, the subject of tax is an individual, an undivided inheritance as a unit to replace those entitled, corporations, and permanent establishment. The subject of the corporate tax referred to here is a group of people and/or capital which is a unit, either doing business or not doing business. These tax subjects are responsible for fulfilling their tax obligations. Meanwhile, the size of the tax to be paid to the state treasury is calculated based on the tax object. The object of income tax is income that is subject to tax, namely any additional economic capacity received or obtained by the Taxpayer, both from Indonesia and from outside Indonesia, which can be used for consumption or to increase the wealth of the Taxpayer concerned, in any name and form. (Direktorat Jenderal Pajak, 2013)

Operating profit in a business entity can be used as a basis for measuring company performance. Companies that have good performance should have high operating profits, and on the other way around if operating profits are low, it can be said that the company has poor performance. Operating profit in taxation is also used as a tax object. The higher the company's income, the higher the tax to be paid. For this reason, it can be concluded that companies that have good financial performance will have a higher contribution to national tax revenues than companies that are not good. (Li et al., 2021)

Based on previous research, the company's financial performance can affect the amount of corporate income tax payments. Good corporate financial performance is expected to have a good effect on tax payments. The liquidity ratio can view the company's ability dala $\mathrm{m}$ sup hi short-term liabilities. Good liquidity condition means the company is financially sound and is expected to increase its sales which will increase its operating profit and corporate income tax. With this liquid condition, it is also expected that the company will not have obstacles in fulfilling its tax obligations, namely paying corporate income tax. (Menichini, 2020)

The profitability ratio is a ratio that is closely related to corporate income tax. With a high profitability ratio, it means that the company can perform cost efficiency which has an impact on increasing operating profit so that the corporate income tax paid to the state will also be high.

In addition to financial performance, corporate income tax is also affected by operating costs, where these costs directly reduce the company's sales or income which has an impact on the company's profit which is used as a tax base. The imposition of large costs will suppress the profits obtained and conversely the imposition of low costs will increase the company's profits. The purpose of this study is to test the effect of liquidity, profitability and operating costs partially or simultaneously on corporate income tax . (Andrejovská et al., 2017)

\section{Effect of Liquidity on Corporate Income Tax}


Based on article 1 of Law no. 36 of 2008 states that income tax is imposed on individuals and entities with respect to income received or earned during the tax year. Income tax is any additional tax on economic capability received or obtained by the taxpayer, both from Indonesia and from outside Indonesia, which can be used for consumption or to increase the wealth of the taxpayer concerned.

So corporate income tax is a tax imposed on tax subjects, namely companies or entities on the object of income tax, namely company profits (Mardiasmo, 2016) stated that, income tax rate uses progresif tax rate namely the percentage of rate used is getting higher when the number of those subject to tax is getting higher. Corporate income tax arises because of the income or profit from the company's operations or sales. The higher the profit generated by the company, the greater the tax that must be paid to the state treasury. To calculate corporate income tax, the company's net profit is multiplied by corporate income tax rate in rupiah, article 17 (Atina et al., 2017).

According to (Kasmir, 2017) Liquidity ratio is a ratio showing the company's ability to pay shortterm debts that are due or the ratio to determine a company's ability to finance and fulfill the obligation at the time billed. In this study, the liquidity ratio using current ratio (CR) is the ratio that measures a company's ability to repay current liabilities using current assets owned. The larger this ratio means the more liquid the company is. However, this ratio has a weakness, because not all components of current assets have the same level of liquidity. In practice it is often used that the current ratio with a standard of $200 \%$ (2:1) is sometimes considered a fairly good or satisfactory measure for a company. According to Puspitasari and Nik Amah (2019) liquidity has an effect on corporate income tax, while according to Anam \& Zuardi (2018) liquidity has no effect on income $\operatorname{tax}$.

\section{Effect of Profitability on Corporate Income Tax}

The profitability ratio is a ratio to assess the company's ability to seek profit (Kasmir, 2017). This ratio also provides a measure of the effectiveness of a company's management. Net profit margin (NPM) is a measure of profit by comparing the profit after interest and taxes compared with sales. This ratio shows the company's net income on sales. The general standard of the industry average for NPM is $20 \%$, if it is above the industry average then the profit margin of a company is good, and vice versa .

Theoretically, the profitability ratio affects the size of the corporate income tax. This is supported by the results of research by Puspitasari and Nik Amah (2019) that shows the effect of profitability of the corporate income tax, whereas the study with the results of no effect of profitability by Atina et al. (2017) it is estimated that the company does not minimize the costs that even though the company generates very high sales, the burden becomes large and has an impact on the decline in net sales.

\section{Effect of Operating Expenses on Corporate Income Tax}

Cost is the cost of goods or services that have provided benefits which is used to earn income. Costs will be deducted from income to determine profit or loss for a period so that costs will be included in the income statement ( $\underline{\text { Siregar et al., 2013). According to Murhadi (2013) }}$ operating costs are costs incurred relating to the operations of the company covering the sales and administrative costs, depreciation costs, advertising costs, as well as repair and maintenance costs. Costs that are allowed to be deducted in calculating domestic taxpayers are costs related to 
business activities (Law No. 36 of 2008). Theoretically operating costs affect corporate income tax. The results showed that there was an effect of operational costs on corporate income tax, among others, found by Anam and Zuardi (2018), Anggraini and Kusufiyah (2020) while Puspitasari and Nik Amah (2019) found no effect.

The theoretical framework of the research can be illustrated in the research model as follows:

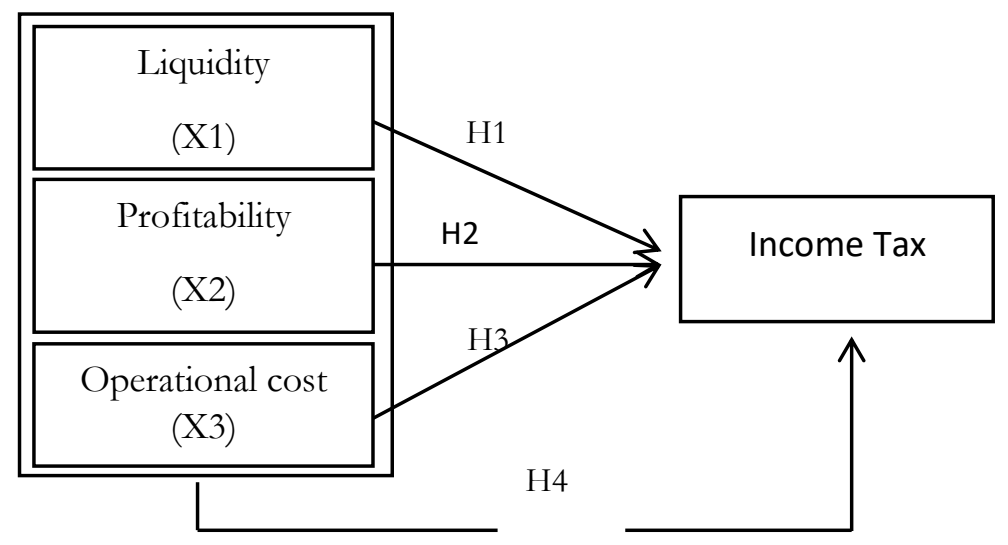

Figure 1. Research Model

\section{Hypothesis:}

H1. Liquidity has partial effect on corporate income tax

H2. Profitability has partial effect on corporate income tax

H3. Operational costs have a partial effect on corporate income tax

H4. Liquidity, profitability and operating costs have a simultaneous effect on corporate income $\operatorname{tax}$.

\section{METHOD}

The object of this study is company of trade, services and investment in major trade subsector (wholesale) listed on the Indonesia Stock Exchange (BEI) for the data period of 20142018. Determination of the sample in this study using the purposive sampling method. Of the 40 companies listed on big trade subsector (wholesale), there are eight companies that can be used as samples with the following criteria :1. No commercial or fiscal losses, 2. The profit/loss report uses the rupiah currency unit. 3. Company data and components in complete financial statements

The analysis used was multiple linear regression analysis which that was processed with the software Statistical Product and Service Solution (SPSS) software version 26. The data sources in the form of financial statements were obtained from www.idx.go.id and www.idnfinancials.co.id.

\section{RESULT AND DISCUSSION}

Based on table 3, the results of the Kolmogorov-Smirnov Test show that the values of liquidity, profitability and operating costs in this study are normally distributed. In this case, it is shown by 


\section{Liquidity, Profitability And Operational Costs On Corporate Income Tax}

Kusrina \& Fatimah

the obtained value of Asymp. Sig . (2-tailed) 0,121 . It can be concluded that the data is normally distributed because the significance value is $0,121>0,05$, so the regression model meets the assumption of normality. Thus the regression model is feasible to be used in research.

Table 3. Normality

One -Sample Kolmogorov-Smirnov Test

\begin{tabular}{|llr|}
\hline & & \multicolumn{1}{c|}{$\begin{array}{c}\text { Unstandardized } \\
\text { Residual }\end{array}$} \\
\hline $\mathrm{N}$ & Mean \\
\hline $\begin{array}{l}\text { Normal } \\
\text { Parameters }\end{array}$ & 0.0000000 \\
\hline & $\begin{array}{l}\text { Std. } \\
\text { Deviation }\end{array}$ & 0.23615215 \\
\hline $\begin{array}{l}\text { Asymp. Sig. } \\
\text { (2-tailed) }\end{array}$ &, $121^{\mathrm{c}}$ \\
\hline Source: Data processed & \\
\hline
\end{tabular}

Multicollinearity testing results shown in Table 4, shows the value Tolarance liquidity of 0,807 , the profitability at 0.880 , and operating expenses amounted to 0,872 . While the value of VIF for liquidity is 1,239 , profitability is 1,136, and operational costs are 1,147 . It can be concluded that the value of liquidity ratios tolerance, profitability and operational costs $\geq 0.10$ and VIF liquidity ratios, profitability and operational costs $\leq 10$. It can be concluded the research data is not the case of multicolinearity and is stated that multicolinearity test is fulfilled.

Table 4 . Multicollinearity Test

\begin{tabular}{|c|c|c|c|}
\hline \multicolumn{4}{|c|}{ Coefficients a } \\
\hline \multirow{2}{*}{\multicolumn{2}{|c|}{ Model }} & \multicolumn{2}{|c|}{ Collinearity Statistics } \\
\hline & & Tolerance & VIF \\
\hline \multirow[t]{3}{*}{1} & Liquidity & 0.807 & 1.239 \\
\hline & Profitability & 0.880 & 1.136 \\
\hline & $\begin{array}{l}\text { Operating } \\
\text { costs }\end{array}$ & 0.872 & 1.147 \\
\hline
\end{tabular}

Source: Data processed

The results of the autocorrelation test in table 5 below show the DW value is 1,869 , this indicates that the DW value is less than 2 , which means there is no autocorrelation .

Table 5. Autocorrelation Test

\begin{tabular}{cccccc}
\hline \multicolumn{6}{c}{ Model Summary $^{\mathrm{b}}$} \\
\hline Model & $\mathrm{R}$ & $\mathrm{R}$ & Adjusted & Std. Error of & Durbin- \\
& & Square & R Square & the Estimate & Watson \\
\hline $\mathbf{1}$ & $0,979 \mathrm{a}$ & 0.959 & 0.956 & 0.24579 & 1.869
\end{tabular}

Source: Data processed

The results of the Heteroscedasticity Test with a scatterplot diagram (figure 2) show that there is no heteroscedasticity because there is no clear pattern and the points spread above and below the number 0 on the $Y$ axis, it can be concluded that there is no heteroscedasticity symptom, so it can be stated the heteroscedasticity test is fulfilled. 


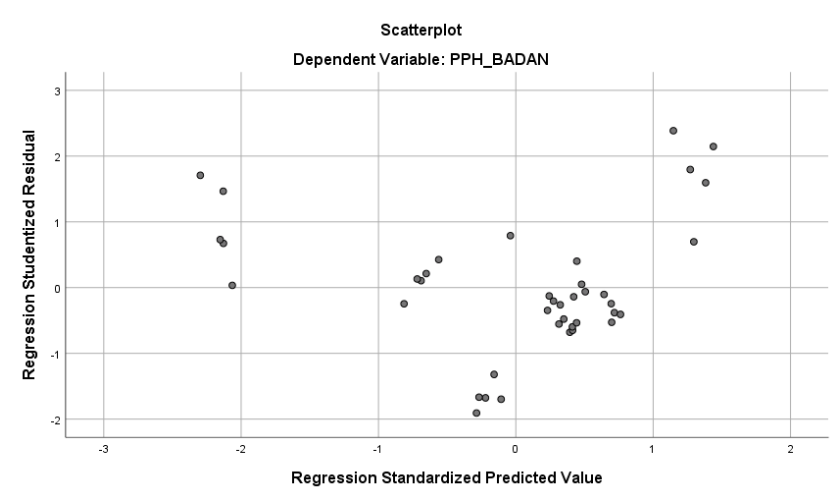

Figure 2

Heteroscedasticity Test Results

Source: Data processed

Based on Table 6, the results of the Multiple Linear Regression Test obtained the regression equation for variables, inflation rates, interest rates, and exchange rates, as follows:

Corporate income tax $=-0,079+0,202 X 1+0,633 X 2+1,026 X 3+\mathrm{e}$

Note: X1: Liquidity

X2: Profitability

X3: Operating Cost

Table 6 . Multiple Linear Regression Test

\begin{tabular}{|c|c|c|c|c|c|}
\hline \multirow[t]{2}{*}{ Model } & \multicolumn{2}{|c|}{$\begin{array}{l}\text { Unstandardized } \\
\text { Coefficients }\end{array}$} & \multirow{2}{*}{$\begin{array}{c}\text { Standardized } \\
\text { Coefficients }\end{array}$} & \multirow[t]{2}{*}{$t$} & \multirow[t]{2}{*}{ Sig. } \\
\hline & $\mathrm{B}$ & Std. Error & & & \\
\hline 1 (Constant) & -0.079 & 0.237 & & -0.334 & 0.740 \\
\hline Liquidity & 0.202 & 0.359 & 0.021 & 0.563 & 0.577 \\
\hline Profitability & 0.633 & 0.104 & 0.219 & 6.104 & 0.000 \\
\hline Operating costs & 1.026 & 0.038 & 0.968 & 26,789 & 0.000 \\
\hline
\end{tabular}

The results of the Partial Test ( $t$ test) obtained the following results:

a. Liquidity based on the test results that the significance value is at 0,577. The significance value is $>0.05$, then $H_{0}$ is accepted or $H_{1}$ is rejected. From these results it can be concluded that the liquidity variable partially has no effect on corporate income tax.

b. Profitability based on the test results that the significance value is at 0,000 . The significance value is $<0.05$, then $H_{0}$ is rejected or $H_{2}$ accepted. From these results it can be concluded that the profitability variable partially affects corporate income tax.

c. Operational costs based on the test results that the significance value is 0,000 . The significance value is $<0,05$ so $H_{0}$ is rejected or $H_{3}$ is accepted. From these results it can be concluded that the operational cost variable partially affects corporate income tax.

Table 7 . Coefficient of Determination 
Liquidity, Profitability And Operational Costs On Corporate Income Tax Kusrina \& Fatimah

\begin{tabular}{|c|c|c|c|c|}
\hline \multicolumn{5}{|c|}{ Model Summary } \\
\hline Model & $\mathrm{R}$ & $\begin{array}{c}\mathrm{R} \\
\text { Square }\end{array}$ & $\begin{array}{l}\text { Adjusted R } \\
\text { Square }\end{array}$ & $\begin{array}{l}\text { Std. Error of the } \\
\text { Estimate }\end{array}$ \\
\hline 1 & $0,979^{a}$ & 0.959 & 0.956 & 0.24579 \\
\hline
\end{tabular}

Source: Data processed

Based on Table 7 Coefficient of Determination is seen that the column of Adjusted R Square at 0,956 shows the magnitude of the role or contribution of independent variables such as liquidity, profitability and operating costs contribute to the corporate income tax amounted to $95.6 \%$. While the rest of $4,4 \%$ is explained by other variables that do not exist in this study.

Table 8 . F Uji test

\begin{tabular}{lrrrrrr}
\hline \multicolumn{7}{c}{ ANOVA a } \\
\hline Model & $\begin{array}{l}\text { Sum of } \\
\text { Squares }\end{array}$ & df & $\begin{array}{c}\text { Mean } \\
\text { Square }\end{array}$ & F & Sig. \\
\hline $\mathbf{1}$ & Regression & 50.934 & 3 & 16.978 & 281.021 &, 000 b \\
\hline & Residual & 2.175 & 36 & 0.060 & & \\
\hline & Total & 53.109 & 39 & & & \\
\hline
\end{tabular}

Source: Data processed

In table 8. Simultaneous Test Results (F) obtained Sig. F 0,000. Value of Sig. F is smaller than 0,05. It can be concluded that the variables of Liquidity, Profitability and Operating Costs are simultaneously affect the corporate income tax.

\section{Effect of Liquidity Ratio on Corporate Income Tax}

The first hypothesis (H1) proposed in this study is that it is suspected that Liquidity has an effect on corporate income tax. The results of the partial $t$ test are known to have a coefficient of 0,202 with a significance level of 0.577 . These results indicate that the liquidity ratio has no effect on Corporate Income Tax. This means that the level of the company's liquidity ratio will not affect the amount of corporate income tax payable. The liquidity ratio, which is a reflection of available current assets, will not directly affect income tax, because current assets are not necessarily all used for company operations which will ultimately increase sales and profits. These results are in accordance with the research by Anam \& Zuardi (2018) and Widanto and Pramudianti (2021) .

\section{The Effect of Profitability Ratios on Corporate Income Tax}

The second hypothesis (H2) is suspected that profitability has an effect on corporate income tax. The regression coefficient for the change in profitability is 0,633 implying that the increase in one-unit change in the profitability of the Corporate Income Tax will have an increase at 0,633 . Based on calculations of significance level at 0,000 , since the significance value is less than 0,05 then in partial, there is influence between profitability with corporate income tax. These results support the results of research by Puspitasari and Nik Amah (2019) which found that there was an effect of profitability on corporate income tax.

\section{Effect of Operating Costs on Corporate Income Tax}


The third hypothesis (H3) is suspected that Operational Costs have an effect on Corporate Income Tax. The regression coefficient for the change in Exchange rate is 1,026 implying that there is an increase of one-unit change Operating Costs so the Corporate Income Tax will increase by 1,026 . Based on the results of the calculation of the significance level of 0,000 , because the significance value is less than 0.05 , so there is a partial effect between Operational Costs and Corporate Income Tax. This research is in line with the research by Anam \& Zuardi (2018) and Vindasari (2019) which states that operational costs have an effect on corporate income tax. This is because operational costs are a determining element of operating profit. So the size of the cost will affect the corporate income tax.

\section{Effect of liquidity, profitability and operating costs on corporate income tax}

The fourth hypothesis (H4) simultaneously has an effect on the ratio of liquidity, profitability and operating costs to corporate income tax. Simultaneous Test Results (F) obtained Sig. F 0,000 means that the variable Liquidity, Profitability and Operating Expenses simultaneously affect the corporate income tax. Supported by the results of the coefficient of determination showing a figure of $95.6 \%$, it means that the independent variables of liquidity, profitability, and operating costs can explain the dependent variable, namely corporate income tax payable of $95,6 \%$, the remaining $4,4 \%$ is caused by other factors that are not used in this study .

\section{CONCLUSION}

Partially liquidity does not effect corporate income tax. The ratio of profitability and operational cost give effects on corporate income tax. Simultaneously, liquidity, profitability and operational cost give effects to corporate income tax. Based on the results obtained that the ratio that affects corporate income tax is profitability and operating costs, so as an implication the internal party/management must be careful with the information presented in the financial statements which will have a negative impact on the users of financial statements, especially on operating costs.

The results of this study are limited to large trading sub-sector companies for the period 20142018 using 3 variables, namely liquidity, profitability and operating costs. Suggestions for further researchers can explore other financial variables that have the potential to affect corporate income tax and expand the sample to be compared with the results of previous studies.

\section{REFERENCE}

Anam, C., \& Zuardi, L. R. (2018). Analisis Rasio Likuiditas, Rasio Solvabilitas, Dan Biaya Operasional Terhadap Pajak Penghasilan Badan Terutang (Sektor Pertambangan Di BEI Tahun 2011-2016). Jurnal Ekonomi Dan Perkembangan Bisnis Margin Eco, 2(1), 43-68. https://doi.org/https://doi.org/10.32764/margin.v2i1.198

Andrejovská, A., Mihóková, L., \& Martinková, S. (2017). Metaanálisis de categorización de los países de la Unión Europea en el contexto del impuesto de sociedades. Contaduria y Administracion, 62(3), 1001-1018. https://doi.org/10.1016/j.cya.2017.04.002

Anggraini, D., \& Kusufiyah, Y. V. (2020). Dampak Profitabilitas, Leverage dan Biaya Operasional Terhadap Pajak Penghasilan Badan. Jurnal Ekonomi Dan Bisnis Dharma Andalas, 22(1), 33-47. https://jurnal.unidha.ac.id/index.php/JEBD/article/view/76 
Atina, I., Harimurti, F., \& Kristianto, D. (2017). Pengaruh Profitabilitas Dan Biaya Operasional Terhadap PPh Badan Perusahaan Makanan Dan Minuman Di BEI (Periode 2013-2015). Jurnal Akuntansi Dan Sistem Teknologi Informasi, 13(3), 323-330. https:// ejurnal.unisri.ac.id/index.php/Akuntansi/article/view/1844

Direktorat Jenderal Pajak. (2013). Undang-Undang KUP dan Peraturan Pelaksanaannya (K. Petrus (ed.); I). Direktorat Jenderal Pajak. https://kemenkeu.go.id/sites/default/files/uu-kup mobile.pdf

Farah, B., Elias, R., Chakravarty, D., \& Beamish, P. (2021). Host country corporate income tax rate and foreign subsidiary survival. Journal of World Business, 56(2), 101186. https://doi.org/10.1016/j.jwb.2020.101186

Ježek, F. (2014). Comparative Research in the Area of Corporate Income Tax. Procedia - Social and Behavioral Sciences, 110, 997-1005. https://doi.org/10.1016/j.sbspro.2013.12.946

Kasmir. (2017). Analisis Laporan Keuangan (Kasmir (ed.); I). RajaGrafindo Persada. https://www.rajagrafindo.co.id/produk/analisis-laporan-keuangan/

Li, B., Liu, C., \& Sun, S. T. (2021). Do corporate income tax cuts decrease labor share? Regression discontinuity evidence from China. Journal of Development Economics, 150(January), 102624. https://doi.org/10.1016/j.jdeveco.2021.102624

Mardiasmo. (2016). Perpajakan (Mardiasmo (ed.); III). Andi. http:/ /www.library.usd.ac.id/web/index.php?pilih=search\&p=1\&q=0000133697\&go=Det ail

Menichini, A. A. (2020). How do firm characteristics affect the corporate income tax revenue? International Review of Economics and Finance, 65(September 2019), 146-162. https://doi.org/10.1016/j.iref.2019.10.004

Murhadi, W. R. (2013). Analisis Laporan Keuangan (Proyeksi dan Valuasi Sabam) (Werner R. Murhadi (ed.); I). Penerbit Salemba. https://penerbitsalemba.com/buku/01-0234-analisis-laporankeuangan-proyeksi-dan-valuasi-saham

Puspitasari, D. A. L., \& Nik Amah. (2019). Pengaruh Profitabilitas Likuiditas dan Biaya Operasional Terhadap Pajak Penghasilan Badan (Studi Pada Perusahaan Manufaktur Sub Sektor Industri Barang Konsumsi Yang Terdaftar di Bursa Efek Indonesia Periode Tahun 2015-2017). Jurnal SIMBA : Seminar Inovasi Manajemen, Bisnis, Dan Akuntansi, 1(1), 474-488. http://prosiding.unipma.ac.id/index.php/SIMBA/article/view/1166

Siregar, B., Suripto, B., Hapsoro, D., Widodo, E., Herowati, E., Kusumasari, L., \& Nurofik. (2013). Akuntansi Biaya (Baldric Siregar (ed.); II). Salemba Empat. https://penerbitsalemba.com/buku/01-0333-akuntansi-biaya-e2

Zhang, Y., \& Huang, J. H. (2014). Cost-based pricing model with value-added tax and corporate income tax for a supply chain network. Applied Mathematical Modelling, 38(1), 168-180. https://doi.org/10.1016/j.apm.2013.06.011 